\title{
Positive reinforcement conditioning as Sumatran tiger's (Panthera tigris sumatrae) social enrichment at Tambling Wildlife Nature Conservation Rescue Centre, Lampung, Indonesia
}

\author{
GENOVEVA KIRANAPUTRI ${ }^{1, \bullet}$, LUTHFIRALDA SJAHFIRDI ${ }^{1}$, LIGAYA ITA TUMBELAKA ${ }^{2}$, ARI YANA ${ }^{3}$, \\ SADMOKO KUSUMO PRIYANTO ${ }^{3}$, LESTY YULIETA ANGGARSARI ${ }^{3}$, MARIZAL ${ }^{3}$ \\ ${ }^{1}$ Department of Biology, Faculty of Mathematics and Natural Science, Universitas Indonesia. Jl. Margonda Raya, Depok 16424, West Java, Indonesia. \\ Tel./fax.: +62-21-7867222, `email: genovv.k@ gmail.com \\ ${ }^{2}$ Department of Veterinary Clinic Reproduction and Pathology, Institut Pertanian Bogor. Jl. Agatis, Kampus IPB Darmaga, Bogor 16680, Indonesia. \\ Tel: $+62-251-8629469$ \\ ${ }^{3}$ Yayasan Artha Graha Peduli, Tambling Wildlife Nature Conservation. 3HM5+X8F, Lampung 34875, Lampung, Indonesia
}

Manuscript received: 15 October 2021. Revision accepted: 8 December 2021

\begin{abstract}
Kiranaputri G, Sjahfirdi L, Tumbelaka LITA, Yana A, Priyanto SK, Anggarsari LY, Marizal. 2021. Positive reinforcement conditioning as Sumatran tiger's (Panthera tigris sumatrae) social enrichment at Tambling Wildlife Nature Conservation Rescue Centre, Lampung, Indonesia. Biodiversitas 23: 55-61. Tiger individuals are translocated to ex-situ conservations due to human-tiger conflicts and may express behavioral change (stereotypic) in captivity. Furthermore, medical check-up routines may cause injury and stress between tiger and operators under tough circumstances. Positive reinforcement conditioning (PRC) is a well-known method to minimize the risks on medical examination and as social enrichment. Therefore, the purposes of this research are (i) to examine PRC on tiger's blood sample collections and (ii) the correlation between physiological stress and tiger's stereotypic behavior (SB) through the neutrophil per lymphocyte ratio (N/L ratio) method. Four Sumatran tigers' (1 female, 3 males) behavior were observed using focal animal sampling at Tambling Wildlife Nature Conservation Rescue Centre, Lampung, Indonesia. Each baseline and post-enrichment tiger's behavioral observations were conducted for 1.920 minutes ( 1 male \& 1 female) and 960 minutes $(2$ males). Then SB was categorized into low $(<33,33 \%)$, intermediate $(33,34-66,66 \%)$ or high $(>66,67 \%)$. Blood collections $(\mathrm{BC})$ were conducted twice $\left(1^{\text {st }}\right.$ without PRC and $2^{\text {nd }}$ with PRC) directly on the tiger after the behavior observation. Tiger's physiological stress during BC was analyzed with Wilcoxon. The correlation between physiological stress and SB was analyzed with Kruskal-Wallis. All tigers' N/L ratios were in normal value from this present research during both BC. The tigers did not show chronic stress as long as this research was conducted. PRC was significantly effective to reduce tiger physiological stress during $B C(Z=-0,730, P=0,465<0,05)$. All tigers showed low $(<33,33 \%)$ pacing SB (without fur-plucking, self-biting, and self-mutilation behavior) both in baseline and post-enrichment. Any furplucking, self-biting \& self-mutilation behaviors were not observed. Physiological stress was not correlated to SB $\left(x^{2}=3, \mathrm{P}=0,392>\right.$ 0,05). The PRC was an appropriate and effective tool to handle Sumatran tigers during BC. These tigers performed SB as a coping mechanism in the enclosure.
\end{abstract}

Keywords: N/L Ratio, PRC, social enrichment, stereotypic, Sumatran tiger

\section{INTRODUCTION}

Tiger population needs to be preserved, although it's facing continuous threats such as deforestation (Luskin et al. 2017; Poor et al. 2019), poaching (Risdianto et al. 2016), and human-animal conflict (Lubis et al. 2020). Tiger individuals are translocated to rescue centers or ex-situ conservations due to human-tiger conflicts. Tiger may express behavioral change (stereotypic) in captivity such as pacing, fur-plucking, self-biting, and self-mutilation (Stanton et al. 2015; Vaz et al. 2017). Those threats and behavioral changes also occur to Sumatran tiger (Panthera tigris sumatrae, Pocock 1929). Sumatran tiger as the only Panthera tigris subspecies left in Indonesia is well-known by its local names such as "Datuk", "Si Mbah" or "Kiai".

Handling a wild animal is risky. Injury between the non-domesticated animal and the operator during blood collection and injection on medical procedure may be present (Grandin 2000). Tiger's attack on its handler has been reported in a modern zoo (Tantius et al. 2016) and unregulated private zoo setting (Schiller et al. 2007). Stress causes abnormalities in medical procedures and diagnostic tests (Rodan 2010). Neutrophil/lymphocyte ratio (N/L ratio) can be applied to measure an animal's stress. Examination of the N/L ratio is a more practical and rapid method than hormonal assays to be performed in the field (Seltmann et al. 2020).

Many species have been successfully conditioned to cooperate with a veterinarian during medical examination (Grandin 2000). Tiger's standard hematological value is mentioned by others researchers (Shriavastav et al. 2012; Allwin et al. 2019). Positive reinforcement conditioning (PRC) using food "rewards" prepares the animal to voluntarily cooperate during blood collection/vein puncture (Coleman et al. 2008). PRC reduces stress during blood collection on antelope, bison (Grandin 2000), dog, and wolf (Vasconsellos et al. 2016) and applies to snow leopards (Broder et al. 2008) lions (Callealta et al. 2019) 
and jaguar (Gracia et al. 2021). Negative reinforcement as "punishment" has been mentioned on the rat (Mayer et al. 2018; Hernandez-Lallement et al. 2020) and dog (China et al. 2020). In conditioning animals, positive reinforcement as a "reward" is more effective than "punishment" (China et al. 2020). "Punishment" impedes the learning process and intensifies anxiety (Rodan 2010). In addition, PRC works as a social enrichment on the tiger (Szokalski et al. 2012). There is no scientific publication about positive reinforcement conditioning in Sumatran tiger yet.

This research focuses on the Sumatran tiger's stereotypical behavior and physiological stress during blood collection. The lower stress level during blood collection may lead to more accurate medical examination and diagnoses. The purposes of this research are to (1) evaluate the effectiveness of PRC on Sumatran tigers' blood collection and (2) examine the correlation between physiological stress and stereotypic behavior through the $\mathrm{N} / \mathrm{L}$ ratio. The results from this research may be valuable and applicable for rescue centers and ex-situ conservations as animal welfare's efforts.

\section{MATERIALS AND METHODS}

\section{Ethical approval}

Ethical clearance of this research was approved by the Ethics and Research Committee at the Faculty of Medicine Universitas Indonesia (No.20-01-0058), Indonesia. All procedures were conducted aseptically and with animal welfare considerations.

\section{Study site and animals}

This research was conducted in Tambling Wildlife Nature Conservation (Tambling) as a part of Bukit Barisan Selatan National Park, Indonesia. Data were collected from 4 adult Sumatran tigers ( 3 males $\& 1$ female) at Tambling Rescue Centre. In this research, those tigers were named Tiger 1, Tiger 2, Tiger 3, and Tiger 4 (female). All tigers were born at Tambling Rescue Centre except for the female tiger (Tiger 4). The female tiger was translocated to Tambling Rescue Centre due to human-tiger conflict at Jambi. Age estimation on those tigers was: 8 years (Tiger 1), 9 years (Tiger 2 and Tiger 3 ), and 20 years (Tiger 4 ). Animal housing and veterinary care were followed Tambling's standard operating procedures and animal welfare principles.

\section{Methods of sampling}

\section{Stereotypic behavior observation}

Tigers' stereotypic behavior was observed using the focal continuous animal sampling method (Altmann 1974; Davis et al. 2018) within a radius of $10 \mathrm{~m}$ in the Tambling's Individual Cage. There was a visual barrier (fence) between the tiger and the observer. The tiger was observed twice $\left(1^{\text {st }}\right.$ as baseline and $2^{\text {nd }}$ as post-enrichment). The stereotypic behavior observation was conducted for almost 2.000 minutes. Tiger $1 \& 2$ were observed for 1.920 minutes, while Tiger $3 \& 4$ were observed for 960 minutes each baseline and post-enrichment behavior observation.
Any fur-plucking, self-biting, self-mutilation, and pacing were noted as stereotypic behavior (Mohapatra et al. 2014; Stanton et al. 2015; Vaz et al. 2017). One observer conducted stereotypic behavior observation for 4 days for each baseline and post-enrichment.

\section{Positive reinforcement conditioning (PRC) and blood collection}

Fresh chicken meats were chosen as a food reward on PRC (Callealta et al. 2019). The fresh chicken meat was parted into 12 pieces. The PRC was conducted in the mechanical restraint cage and only given to the tiger at the $2^{\text {nd }}$ blood collection. Each tiger was granted a minimum of 3 pieces of chicken meat during the blood collection. The chicken meat was given to the tiger piece by piece during the blood collection. Then each tiger was granted 5 pieces of chicken meat after the blood collection.

Blood samples were collected with a mechanical restraint cage and without anesthesia induction. Standard blood collection was performed $<3$ minutes with safety and animal welfare consideration (Allwin et al. 2019). Once the tiger was restrained, blood $(0,5 \mathrm{~mL})$ was collected through a coccygeal vein using a sterile syringe $(3 \mathrm{~mL})$ and needle $(22 \mathrm{G})$. Blood smears were made directly from fresh blood after blood collection. The sterile object glass was given an eye drop of fresh blood ( $1^{\text {st }}$ object glass). Then, another sterile object glass ( $2^{\text {nd }}$ object glass) was attached within $\pm 30^{\circ}$ angle (Rebar et al. 2001; Theml et al. 2004) to the dropped fresh blood and pushed gently to make the blood smear. Methanol was used for blood smear fixation (2-3 minutes) (Bakhri 2018).

\section{Blood smears staining}

This research occurred on the field (outdoor condition). Blood smears fixation was done near the mechanical restraint cage. Furthermore, blood smears staining was conducted within the rescue center area but in a different location from the mechanical restraint cage. Therefore, location with room temperature, no direct sunlight, and rain/windy weather was preferred for blood smears staining to minimize the debris.

Blood smears were stained with Giemsa-Wright solution. After which, it was dipped into Wright's solution for 2 minutes. Blood smears were rinsed slowly using aquadest then dipped into 10\% Giemsa solution for 15 minutes (Ardina and Roslinda 2018). After dipping in Giemsa solution, blood smears then rinsed slowly using aquadest. Blood smears were let to dry before N/L calculation under the microscope.

\section{Neutrophil/lymphocyte ratio (N/L ratio) count}

Differential leucocyte was observed under $\times 40-400$ microscope magnification. Each neutrophil and lymphocyte were counted within 200 white blood cells under the microscope (Kerr 2002; Theml et al. 2004; Shiravastav et al. 2012). Then the counted neutrophils were manually divided by counted leucocytes to obtain the N/L ratio (Dhabhar et al. 1996; Stockman et al. 2011; Seltmann et al. 2020). 


\section{Statistical analysis}

Duration (minutes) of stereotypical behavior recorded was transformed to a percentage (\%) for a more straightforward interpretation. The mean of stereotypic behavior (baseline and post-enrichment) from each tiger was analyzed descriptively using Microsoft Excel $^{\circledR}$ software. Stereotypic behavior was categorized as low $(<33.33 \%)$, intermediate $(33.34-66.66 \%)$ or high $(>66.67 \%)$. Baseline (control) and post-enrichment (PRC) $\mathrm{N} / \mathrm{L}$ ratios were analyzed with Wilcoxon to investigate physiological stress during blood collection. The correlation between physiological stress and stereotypic behavior was analyzed with Kruskal-Wallis. $\operatorname{SPSS}^{\circledR} 25$ software was used for both Wilcoxon and Kruskal-Wallis analysis.

\section{RESULTS AND DISCUSSION}

\section{Results}

PRC effectiveness during blood collection as social enrichment

Tigers expressed calmed behavior within the mechanical cage (Figure 1), although they would not enter the mechanical restraint cage voluntarily. Therefore, the tiger must be lured with fresh chicken meat to enter the mechanical restraint cage by the Tambling's keeper. Blood collection was conducted after the tiger felt relaxed and calmed down in the mechanical restraint cage. Sudden noises and moves should be minimized during blood collection ( $<3$ minutes) (Figure 2$)$. Fresh chicken meats were given to distract the tiger's focus during the blood collection and as food reward after the blood collection. One operator gave parted chicken meat to the tiger by following the tiger's reactions and focuses. Each individual had a different speed when consuming the parted chicken meat.

Neutrophils and lymphocytes were observed under the microscope (Table 1, Figure 3). N/L ratio could be counted manually in the remote area. Statistical analysis showed that PRC significantly reduced physiological stress during blood sample collection $(\mathrm{Z}=-0,730, \mathrm{P}=0,465<0,05)$. Despite physiological stress reduction, all tigers expressed alert/cautious and aggressive behaviors towards human.

\section{Stereotypic behavior and the correlation to physiological stress}

All tigers performed low stereotypic $(<33,33 \%)$ pacing behavior (Table 2, Figure 4). All tigers did not express any self-biting, self-mutilation, or fur-plucking behavior. Statistical analysis indicated that there was no correlation between physiological stress (N/L ratio) and stereotypic behavior $\left(\chi^{2}=3, \mathrm{P}=0,392>0,05\right)$.

Table 1. N/L Ratio of each tiger during blood collection

\begin{tabular}{|c|c|c|c|c|c|c|}
\hline Tiger & $\begin{array}{c}\text { Baseline } \\
\text { (without PRC) }\end{array}$ & $\begin{array}{c}\text { Post-enrichment } \\
\text { (with PRC) }\end{array}$ & Tiger & Observation & Baseline & $\begin{array}{c}\text { Post- } \\
\text { enrichment }\end{array}$ \\
\hline Tiger 1 & 1.52 & 2.03 & Tiger 1 & 1.920 minutes of & $14.95 \%$ & $12.29 \%$ \\
\hline Tiger 2 & 3.33 & 1.68 & Tiger 2 & observation & $29.84 \%$ & $13.07 \%$ \\
\hline Tiger 3 & 0.83 & 1.57 & Tiger 3 & 960 minutes of & $22.29 \%$ & $5.63 \%$ \\
\hline Tiger 4 & 5.2 & 1.67 & Tiger 4 & observation & $17.92 \%$ & $16.04 \%$ \\
\hline
\end{tabular}
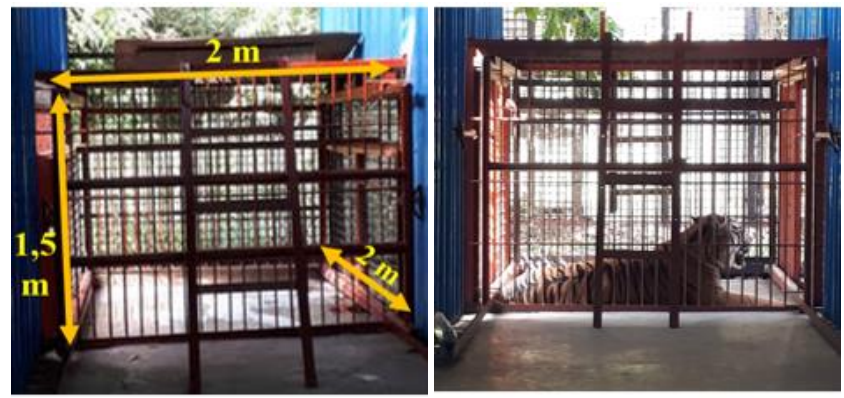

Figure 1. An individual tiger performed calmed behavior in the mechanical restraint cage

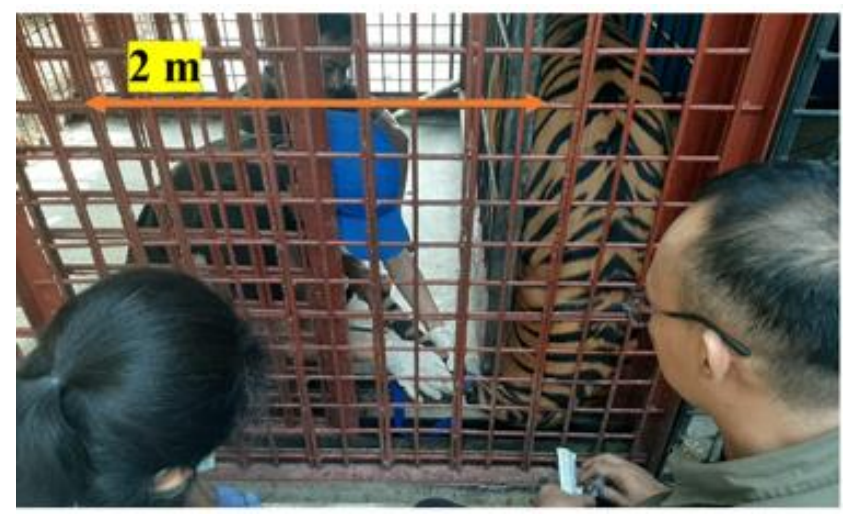

Figure 2. Tiger's blood collection through a coccygeal vein in the mechanical restraint cage

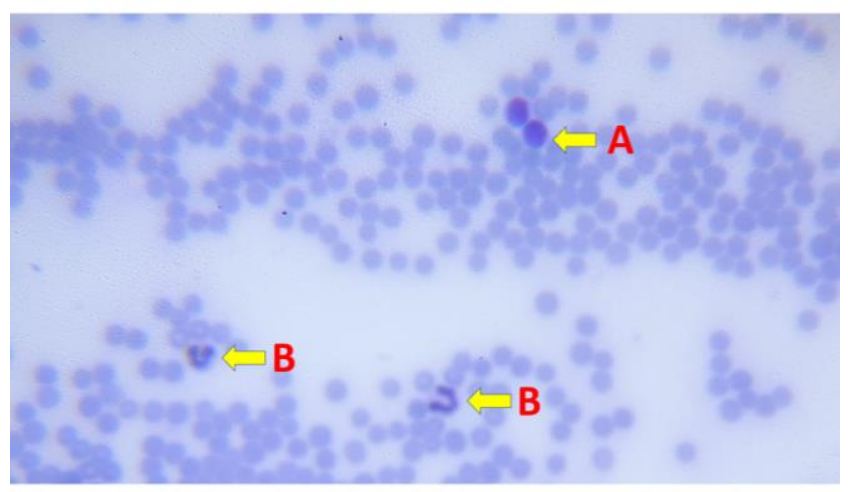

Figure 3. Documentation of lymphocyte (A) and neutrophil (B) count under $\times 40-400$ microscope magnification

Table 2. Mean of tiger's stereotypic behavior 


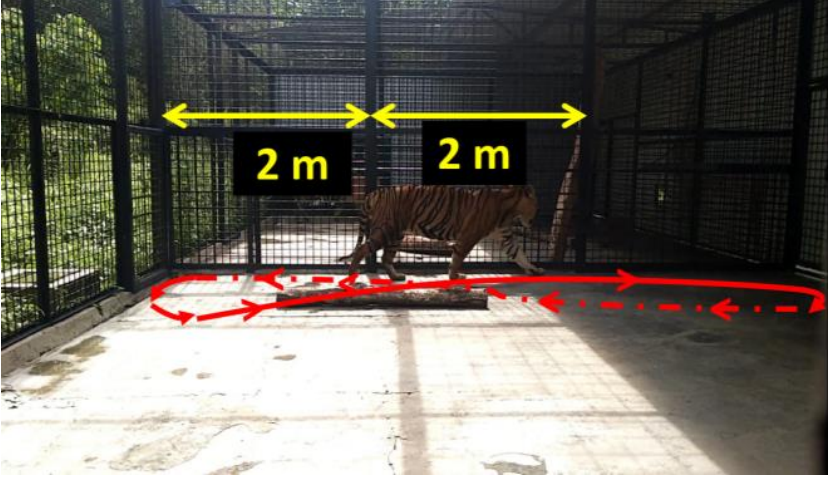

Figure 4. The route of the tiger's pacing behavior is almost similar to number "8" (showed by red lines or -

\section{Discussion \\ Effect of PRC on N/L ratio as a social enrichment}

This present research showed tiger's N/L ratio differed for each individual after PRC. Descriptively, the tiger's N/L ratio was increased after PRC on Tiger 1 (from 1.52 to 2.03) and Tiger 3 (from 0.87 to 1.57). Meanwhile, Tiger 2 (from 3.33 to 1.68 ) and Tiger 4 (from 5.2 to 1.67) were reduced. All four tiger's N/L ratios were statistically analyzed with Wilcoxon and resulted from the that tiger's $\mathrm{N} / \mathrm{L}$ ratio was significantly reduced $(\mathrm{Z}=-0,730, \mathrm{P}=0,465<$ $0,05)$ with PRC. Its implied PRC could minimize distress during blood collection on the tiger. This is consistent with other research (Callealta et al. 2019), which successfully conducted PRC on African lions.

All Sumatran tigers' N/L ratio from this study were within the normal range of tigers' N/L ratio values. Even though Tiger 4's N/L ratio resulted in 5.2 at the 1st blood collection (without PRC), Tiger 4 was not in distress when this research was conducted. Naidenko and Alshinetskiy (2020) research large Felidae white blood cells including tigers' N/L ratio at zoos. The normal value of N/L ratio for large Felidae is $0-5.3$. The $\mathrm{N} / \mathrm{L}$ ratio value above 5.3 is considered as stress. They also explain that large Felidae has more neutrophils and monocytes than small Felidae. The number of lymphocytes is fewer in large Felidae than in small Felidae.

Abnormalities due to physiological stress on medical examination and diagnostic tests have been reported. Tachycardia, bradycardia, rapid breathing, pupil dilatation, hyperthermia, stress colitis, and urination may appear during the medical examination. While on the diagnostic test may appear on the complete blood count (platelet hypersensitivities, lymphocytosis, neutrophilia), blood chemistry (hyperglycemia, hypokalemia under epinephrin release), urine analysis ( $\mathrm{pH}$ level alteration), and hypertension (Rodan 2010). Stress influences physiological conditions such as; immune system activation (Hellhammer et al. 2010; Narayan et al. 2017), metabolism, cardiovascular function, reproduction, behavior, and cognition (Narayan et al. 2017). Physiological changes appear as responses to the stressor/stimuli (Narayan et al. 2017). Stressor bothers physical's homeostatic then initiates flight or fight response. Flight or fight response involves autonomous activities and metabolic changes in an organism to adjust to the environment (Morgan and Tromborg 2007).

Stress and glucocorticoid treatment can increase neutrophils (neutrophilia). Glucocorticoid reduces lymphocytes (Sapolsky et al. 2000; Davis et al. 2008; Valenciano et al. 2010), eosinophils (Valenciano et al. 2010), basophils, macrophages, and monocytes (Sapolsky et al. 2000). N/L ratio escalates due to stressors (Schaefer et al. 1997; Davis et al. 2008). N/L ratio as stress measurement has been researched on cows (Stockmann et al. 2011), rhesus macaques (Lee et al. 2012), ebony leaf monkeys (Danafi et al. 2017; Titisari et al. 2019), and bats (Seltmann et al. 2017).

Species may adapt to cope (coping response) through stressing environment (stressor) (Hofer and East 1998; Sapolsky et al. 2000; Narayan et al. 2017) and anthropogenic disturbances (Hofer and East 1998). Stress is a component of a tiger's life cycle and is not inherited. Stress prepares individuals to perform hunting behavior, mating behavior, and feeding behavior (Narayan et al. 2017). Abiotic environmental stressor on wild animal has been recorded (Morgan and Tromborg 2007). In both environments, whether it's in captivity (ex-situ) or in the wild (in-situ), individuals will meet stressors in their environment. Not only from the anthropogenic disturbances, but also habitat factors will influence tigers' stress level. Malviya et al. (2018) study habitat factors such as canopy cover and shrub abundance that contributed to tiger's stress levels in India. Another factor contributing as a stressor in the wild is prey availability for tigers.

Visitors were restricted unless for conservation education and research considerations at the rescue center. Under that circumstances, blood collection (medical examination) with PRC on those tigers was categorized as social enrichment. This research supported scientific evidence regarding PRC as social enrichment for the tiger in line with Szokalski et al. (2012). The effect of the visitor on the animal behavior was reported from other researches (Sellinger and Ha 2005; Vidal et al. 2016; Suárez et al. 2017). Previous studies classified visitors as having negative interaction for animal welfare in zoos due to stress conditions for the animal. Contrary to Suárez et al. (2017), this research emphasized the positive human-animal interaction for animal welfare and aligned with Cole and Fraser (2018). Therefore, PRC was very beneficial in handling the Sumatran tiger during blood sample collection and as a tool to implement animal welfare in captivity.

\section{The correlation between stereotypic behavior and physiological stress}

Behavioral observation and physiological indicators were elaborated in this research. In line with other researches (Davis et al. 2008; Seltmann et al. 2020), this present research showed that the $\mathrm{N} / \mathrm{L}$ ratio could be used as a physiological stress indicator in the field or remote area. Behavior observation was merely enough to measure stress response (Hofer and East 1998). Hematological value has essential information on effectively managing translocation and rehabilitation (Shanmugam et al. 2017). 
The physiological parameter in this research represented no chronic stress after blood collection. All tigers also expressed feeding behavior after the blood was collected. According to previous research, the N/L ratio is more relevant to measuring acute stress conditions than chronic stress. Cortisol hormonal assay is more suitable for chronic stress than N/L ratio. Cortisol serum in the blood increases during animal restraint, while the N/L ratio is not influenced by blood collection (Swan and Hickman 2014).

Unexpectedly, there was no correlation between stereotypic behavior and physiological stress. A possible explanation was the tiger had reached a homeostatic state at the captivity and was found to be adapted to their new environment. As within the area of Bukit Barisan Selatan national park, Tambling Rescue Centre provided a natural enclosure for those tigers. Tigers were conditioned solitary in the Individual Cage $(6 \mathrm{~m} \times 6 \mathrm{~m})$ and routinely transferred to the Habitual Cage $(135 \mathrm{~m} \times 57 \mathrm{~m})$ with natural settings (every 1-2 weeks). This result highlighted other researches which stated that the animal expressed stereotypic behavior as a coping mechanism (Chosy et al. 2014). Tigers may live to co-exist in the human landscape (Carter et al. 2012; Struebig et al. 2018). The tiger may express pacing behavior due to external stimuli (captivity) and anticipation of a certain event (Krawczel et al. 2005). Contrary to previous research (Vaz et al. 2017), which recorded stereotypic behavior appearing due to stress conditions.

All tigers in this research performed aggressive behavior toward humans and tended to avoid humans. One phenomenon was observed within the overall observation in this research. Tiger 4 chooses to stalk and attack one keeper than live prey (boar) during feeding time. Fortunately, there were fences as barriers between the tiger and the keeper. The individual variation could not be separated for research despite the small sample size. From the previous study, individual variation has a biological function (Koolhas 2008). Coping mechanisms variation and personalities determine evolution competence (Sih et al. 2004; Bell 2007). Aggressive behavior is a crucial trait in surviving or adapting (Bell 2007).

According to previous research, lion species outsmart tiger species in problem-solving experiments. Social being has higher persistence than asocial being (Borrego and Gaines 2016). Social species (such as cats, humans, dogs, and horses) can learn social skills within species (speciesspecific skills). Social experiments within species are fundamental for social behavior development (CorwellDavis et al. 2004; Ahola et al. 2017). Without social skills, an individual will fail to recognize and respond to the signals from another individual (greeting, submissive, dominance) and also increase stereotypic and aggression (Ahola et al. 2017). Newly introduced Sumatran tiger has been recorded to interact affiliative towards other tiger in Osnabrücker zoo (Schimmelphennig et al. 2017).

Despite the small sample size of this research (only four tigers), any information for the wild protected animal is valuable for conservation. Sample collections on this research were planned to reduce human-animal contact as minimum as possible. Other research already mentioned the animal welfare and ethic for the wild animal with 3Rs (Reduce, Refine and Replace) (Soulsbury et al. 2002).

Behavioral changes in free-ranging animals were recorded by other researchers (Kerley et al. 2002; Muhly et al. 2011; Smith et al. 2015; Suraci et al. 2019). Freeranging species also expressed behavioral changes by force of anthropogenic disturbances. Human activities modify the habitats, which indirectly impacts animal behavior (Smith et al. 2015). Human activities potentially change the predator-prey interactions (Muhly et al. 2011). For example, the female Amur tiger is interested in the road made by humans. Those tigers used the road as a corridor within the tiger territorial-ranged. It increases the female tiger's mortality risks and reproduction failure (Kerley et al. 2002).

Although there was no correlation between physiological stress and stereotypic behavior in this research, stereotypic behavior should not be underestimated. Enrichment techniques are required to support animal welfare. Another study noted that novel enrichment techniques (Gomes et al. 2019; Clayton and Shrock 2020) and experience (Clayton and Shrock 2020) should be explored for tiger enrichment. Enrichment techniques must be suitable for species-specific behavior (AZA 2016). Therefore, any fur-plucking/self-biting/selfmutilation (another form of tiger's stereotypic behavior) could be prevented from being expressed by Sumatran tigers in captivity.

The outcome from this research is emphasizing PRC effectiveness during blood collection and minimizing physiological bias on medical examination on Sumatran tiger. It also provides social enrichment (as animal welfare implementation) for the Sumatran tiger. Therefore, PRC should be conducted in tigers' ex-situ conservation. In addition, N/L ratio is an efficient method to be performed on the field to measure the tigers' physiological stress. Sumatran tigers also may perform pacing behavior as a coping mechanism in captivity.

\section{ACKNOWLEDGEMENTS}

The authors would like to express genuine gratitude for the opportunity to conduct this research on Tambling Wildlife Nature Conservation. The authors would like to say thanks to Balai Konservasi Sumber Daya Alam \& Lembaga Ilmu Pengetahuan Indonesia for supporting this research. Last but not least, for all the veterinarians, staff, and rangers who lived daily life in the conservation area.

\section{REFERENCES}

Ahola MK, Vapalahti K, Lohi H. 2017. Early weaning increases aggression and stereotypic behavior in cats. Sci Rep 7 (1): 1-9. DOI: 10.1038/s41598-017-11173-5.

Allwin B, Kalaignan PA, Kanniappan S, Vairamuthu S, Javathangarai MG. 2019. Hematological and serum biochemical indices of captive Royal Bengal tigers (Panthera tigris), Arignar Anna Zoological Park, Candaloor, Chennai. Indian J Anim Res 53: 1613-1618. DOI: 10.18805/ijar.B-3718. 
Altmann J. 1974. Observational study of behavior: Sampling methods. Behavior 49: 227-267. DOI: 10.1163/156853974x00534.

Ardina R, Roslinda S. 2018. Morfologi eosinofil pada apusan darah tepi menggunakan pewarnaan Giemsa, Wright, dan kombinasi WrightGiemsa. J Surya Medika 3 (2): 5-12. DOI: 10.33084/jsm.v3i2.91. [Indonesian]

Association of Zoos \& Aquariums (AZA). 2016. Association of Zoos \& Aquariums (AZA) Tiger Species Survival Plan. 2016. Tiger (Panthera tigris) Care Manual. Association of Zoos and Aquarium, Silver Spring, MD, US.

Bakhri S. 2018. Analisis jumlah leukosit dan jenis leukosit individu yang tidur dengan lampu menyala dan yang dipadamkan. J Media Analisis Kesehatan 1 (1): 83-91. DOI: 10.32382/mak.v1i1.176. [Indonesian]

Bell AM. 2007. Evolutionary biology: Animal personalities. Nature 447 (7144): 539-540. DOI: 10.1038/447539a.

Borrego N, Gaines M. 2016. Social carnivores outperform asocial carnivores on an innovative problem. Anim Behav 114: 21-26. DOI 10.1016/j.anbehav.2016.01.013

Broder JM, MacFadden AJ, Cosens LM, Rosenstein DS, Harrison TM. 2008. Use of positive reinforcement conditioning to monitor pregnancy in an unanesthetized snow leopard (Unica uncia) via transabdominal ultrasound. Zoo Biol 27 (1): 78-85. DOI: 10.1002/zoo.20164.

Callealta I, Lueders I, Luther-Binoir I. Ganswindt A. 2019. Positive reinforcement conditioning as a tool for frequent minimally invasive blood and vaginal swab sampling in African lions (Panthera leo). J Appl Anim Welf Sci 23 (4): 508-519. DOI: 10.1080/10888705.2019.1709066.

Carter NH, Shrestha BK, Karki JB, Pradhan NMB, Liu J. 2012. Coexistence between wildlife and humans at fine spatial scale. Proc Natl Acad Sci USA 109 (38): 15360-15365. DOI 10.1073/pnas.1210490109

China L, Mills DS, Cooper JJ. 2020. Efficacy of dog training with and without remote electronic collars vs a focus on positive reinforcement. Front Vet Sci 7 (507): 1-11. DOI 10.3389/fvets.2020.00508.

Chosy J, Wilson M, Santymire R. 2014. Behavioral and physiological responses in Felids to exhibit construction. Zoo Biol 33: 267-274. DOI: $10.1002 /$ zoo.21142

Clayton M, Shrock T. 2020. Making a tiger's day: Free-operant assessment and environmental enrichment to improve the daily lives of captive Bengal tigers (Panthera tigris tigris). Behav Anal Pract 13 (4): 883-893. DOI: 10.1007/s40617-020-00478-Z.

Cole J, Fraser D. 2018. Zoo animal welfare: The human dimension. J Appl Anim Welf Sci 21 (S1): 49-58. DOI 10.1080/10888705.2018.1513839.

Coleman K, Pranger L, Maier A, Lambeth SP, Perlman JE, Thiele E, Schapiro SJ. 2008. Training rhesus macaques for venipuncture using positive reinforcement techniques: A comparison with chimpanzees. J Am Assoc Lab Anim Sci 47 (1): 37-41.

Corwell-Davis SL, Curtis TM, Knowles RJ. 2004. Social organization in the cat: A modern understanding. J Feline Med Surg 6: 19-28. DOI: 10.1016/j.jfms.2003.09.013.

Danafi ED, Winarso D, Swatomo R, Fauzi A, Masnur I, Kurniawan I Titisari N. 2017. Perbedaan tingkat stres lutung jawa (Trachypitecus auratus) pada kandang perawatan dan kandang karantina di Javan Lengur Center (JLC) ditinjau dari kadar kortisol dan rasio neutrofil perlimfosit. J Ternak Tropika 18 (2): 29-36. DOI: 10.21776/ub.jtapro.2017.018.02.6. [Indonesian]

Davis AK, Maney DL, Maerz JC. 2008. The use of leukocyte profiles to measure stress in vertebrates: A review for ecologists. Func Biol 22 760-772. DOI: 10.1111/j.1365-2435.2008.01467.x.

Davis GH, Crofoot MC, Farine DR. 2018. Estimating the robustness and uncertainty of animal social networks using different observational methods. Anim Behav 141: 29-44. DOI: 10.1016/j.anbehav.2018.04.012.

Dhabhar FS, Miller AH, McEwen BS, Spencer RL. 1996. Stress-induced changes in blood leukocyte distribution. Role of adrenal steroid hormones. J Immunol 157 (4): 1638-1644.

Gomes D, McSweeney L, Santos M. 2019. Effects on environmental enrichment techniques on stereotypical behaviors of captive Sumatran tigers: A preliminary case study. J Anim Behav Biometeorol 7: 144 148. DOI: $10.31893 / 2318-1265$ jabb.v7n4p144-148.

Gracia LCF, Dallago B, Dantas LGD, Bernal FEM. 2021. Effects of conditioning on the welfare of jaguars (Panthera onca) in captivity.
Arq Bras Med Vet Zootec 73 (5): 1076-1084. DOI: 10.1590/16784162-12275.

Grandin T. 2000. Habituating antelope and bison to cooperate with veterinary procedures. J Appl Anim Welf Sci 3 (3): 253-261. DOI: 10.1207/S15327604JAWS0303_6.

Hellhammer DH, Stone AA, Hellhammer J, Broderick J. 2010. Measuring stress. In: Koob GF, Le Moal M, Thompson RF (eds). Encyclopedia of Behavioral Neuroscience, Volume 2. Oxford Academic Press, Oxford, UK. DOI: 10.1016/B978-0-08-045396-5.00188-3.

Hernandez-Lallement J, Attah AT, Soyman E, Pinhal CM, Gazzola V, Keysers C. 2020. Harm to others acts as a negative reinforcer in rats. Curr Biol 30 (6): 1-13. DOI: 10.1016/j.cub.2020.01.017.

Hofer H, East ML. 1998. Biological conservation and stress. In: Slater PJB, Anders PM, Milinski M (eds). Advances in the Study on Behavior, Volume 27. Academic Press, Massachusetts, US. DOI: 10.1016/S0065-3454(08)60370-8.

Kerley LL, Goodrich JM, Miquelle DG, Smirnov EN, Quigley HB, Hornocker MG. 2002. Effects of roads and human disturbance on Amur tigers. Conserv Biol 16 (1): 97-108. DOI: 10.1046/j.15231739.2002.99290.x.

Kerr MG. 2002. Veterinary Laboratory Medicine: Clinical Biochemistry and Haematology 2nd Edition. Blackwell Publishing, Australia.

Koolhas JM. 2008. Coping style and immunity in animals: Making sense of individual variation. Brain Behav Immun 22: 662-667. DOI: 10.1016/j.bbi.2007.11.006.

Krawczel PD, Friend TH, Windom A. 2005. Stereotypic behavior of circus tigers: Effects of performance. Appl Anim Behav Sci 95: 189198. DOI: 10.1016/j.applanim.2005.04.010.

Lee JI., Jun-Seop Sh, Ji-Eun L, Won-Young J, Gaeul L, Min-Sun K, Chung-Gyu P, Sang-Joon K. 2012. Changes of N/L ratio and cortisol levels associated with experimental training in untrained rhesus macaques. J Med Primatol 42: 10-14. DOI: 10.1111/jmp.12023.

Lubis MI, Pusparini W, Prabowo SA, Marthy W, Tarmizi, Andayani N, Linkie M. 2020. Unraveling the complexity of human-tiger conflicts in the Leuser ecosystem, Sumatra. Anim Conserv 23 (6): 741-749. DOI: $10.1111 / \mathrm{acv} .12591$.

Luskin MS, Albert WR, Tobler MW. 2017. Sumatran tiger survival threatened by deforestation despite increasing densities in parks. Nat Comm 8 (1783): 1-9. DOI: 10.1038/s41467-017-01656-4.

Malviya M, Kumar V, Mandal D, Sarkar MS, Nigam P, Gopal R, Sankar K, Umupathy G, Ramesh K. 2018. Correlates of physiological stress and habitat factors in reintroduction-based recovery for tiger (Panthera tigris) populations. Hystrix It J Mamm 29 (2): 195-201. DOI: 10.4404/hystrix-00063-2018.

Mayer PCMM, Neto MCdC, Katz JL. 2018. Punishment and the potential negative reinforcement with histamine injection. J Exp Anal Behav 109: 365-379. DOI: 10.1002/jeab.319.

Mohapatra RK, Panda S, Acharya UR. 2014. Study on activity pattern and incidence of stereotyping behavior in captive tigers. J Vet Behav 9: 172-176. DOI: 10.1016/j.jveb.2014.04.003.

Morgan KN, Tromborg CT. 2007. Source of stress in captivity. Appl Anim Behav Sci 102: 262-302. DOI: 10.1016/j.applanim.2006.05.032.

Muhly TB, Semeniuk C, Massolo A, Hickman L, Musiani M. 2011. Human activity helps prey win the predator-prey space race. PLoS One 6 (3): 1-8. DOI: 10.1371/journal.pone.0017050.

Naidenko SV, Alshinetskiy MV. 2020. Size matters: Zoo data analysis shows that the white blood cell ratio differs between large and small felids. Animals 10 (940): 1-13 DOI: 10.3390/ani10060940.

Narayan E, Baskaran N, Vaz J. 2017. Conservation physiology of tigers in zoo. In: Shiravastav AB, Singh KP (eds). Integrating stress physiology and behavior to monitor their health and welfare. Big Cats. InTech, Croatia. DOI: 10.5772/intechopen.69780.

Poor EE, Shao Y, Kelly MJ. 2019. Mapping and predicting forest loss in Sumatran tiger landscape from 2002 to 2050. J Environ Manage 231: 397-404. DOI: 10.1016/j.jenvman.2018.10.065.

Rebar AH, MacWilliams PS, Feldman BF, Metzger FL, Pollock RVH, Roche J. 2001. A Guide to Hematology in Dogs and Cats. Tenton New Media, USA. DOI: 10.1201/b16159.

Risdianto D, Martyr DJ, Nugraha RT, Harihar A, Wibisono HT, Haidir IA, Macdonald DW, D'Cruze N, Linkie M. 2016. Examining the shifting patterns of poaching from a long-term law enforcement intervention in Sumatra. Biol Conserv 204: 306-312. DOI: 10.1016/j.biocon.2016.10.029

Rodan I. 2010. Understanding feline behavior and application for appropriate handling and management. Top Companion Anim Med 25 (4): 178-188. DOI: 10.1053/j.tcam.2010.09.001. 
Sapolsky RM, Romero LM, Munck AU. 2000. How do glucocorticoids influence stress response? Integrating permissive, suppressive, stimulatory, and preparative actions. Endocr Rev 21(1): 55-89. DOI: 10.1210/edrv.21.1.0389.

Schaefer AL, Jones SDM, Stanley RW. 1997. The use of electrolyte solutions for reducing transport stress. J Anim Sci 75: 258-265. DOI: 10.2527/1997.751258x.

Schiller HJ, Cullinane D, Sawyer MD, Zietlow SP. 2007. Captive tiger attack: Case report and review of the literature. Am Surg 73 (5): 516 519. DOI: $10.1177 / 000313480707300520$.

Schimmelphennig A, Bininda-Emonds ORP, Boer M, Gansloßer U. 2017. Acclimatisation and pair format of two newly introduced Sumatran tigers (Panthera tigris sumatrae, Pocock 1929) in Osnabrücker zoo. Zoologische Garten 86 (2017): 235-247. DOI 10.1016/j.zoolgart.2017.04.008.

Sellinger RL, Ha JC. 2005. The effects of visitor density and intensity on the behavior of two captive jaguars (Pantera onca). J Appl Anim Welf Sci 8 (4): 233-244. DOI: 10.1207/s15327604jaws0804 1.

Seltmann A, Czirják GA, Courtiol A, Bernard H, Struebig MJ, Voight CC. 2017. Habitat disturbance results in chronic stress and impaired health status in forest-dwelling paleotropical bats. Conserv Physiol 5: 1-14. DOI: 10.1093/conphys/cox020.

Seltmann MW, Ukonaho S, Reichert S, Santos DD, Nyein UK, Htut W, Lummaa V. 2020. Faecal glucocorticoid metabolites and H/L ratio are related markers of stress in semi-captive Asian timber elephants. Animals 10 (94): 1-16. DOI: 10.3390/ani10010094.

Shanmugam AA, Muliya SK, Suresh S, Nath A, Kalaignan P, Ventakaravanappa M, Jose L. 2017. Baseline hematology and serum biochemistry results for Indian leopards (Panthera pardus fusca). Vet World 10 (7): 818-824. DOI: 10.14202/vetworld.2017.818-824.

Shiravastav AB, Singh KP, Mittal SK, Malik PK. 2012. Haematological and biochemical studies in tigers (Panthera tigris tigris). Eur J Wildl Res 58: 365-367. DOI: 10.1007/s10344-011-0545-7.

Sih A, Bell AM, Johnson JC, Ziemba RE. 2004. Behavioral syndromes. Q Rev Biol 73 (3): 241-277. DOI: 10.1086/422893.

Smith JA, Wang Y, Wilmers CC. 2015. Top carnivores increase their kill rates on prey as a response to human-induced fear. Proc R Soc B 282: 1-6. DOI: $10.1098 / \mathrm{rspb} .2014 .2711$.

Saulsbury C, Gray H, Smith L, Braithwaite V, Cotter S, Elwood RW, Wilkinson A, Collins LM. 2002. The welfare and ethics of research involving wild animals: A primer. Methods Ecol Evol 11 (10): 1164 1181. DOI: 10.1111/2041-210X.13435.

Stanton LA, Sullivan MS, Fazio JM. 2015. A standardized ethogram for Felidae: A tool for behavioral researches. Appl Anim Behav Sci 173: 3-16. DOI: 10.1016/j.applanim.2015.04.001.

Stockman CA, Collins T, Barnes AL, Miller D, Wickham SL. 2011 Qualitative behavioral assessment and qualitative physiological measurement of cattle naïve and habituated to road transport. Anim Prod Sci 51(3): 240-249. DOI: 10.1071/AN10122.

Struebig MJ, Linkie M, Deere NJ, Martyr DJ, Millyanawati B, Faulkner SC, Le Comber SC, Mangunjaya FM, Leader-Williams N, McKay JE, St. John FAV. 2018. Addressing human-tiger conflict using socioecological information on tolerance and risk. Nat Commun 9: 1-9. DOI: $10.1038 / \mathrm{s} 41467-018-05983-y$.

Suárez P, Recuerda P, Arias-de-Reyna L. 2017. Behavior and welfare: The visitor effect in captive felids. Anim Welf 26: 25-34. DOI: 10.7120/09627286.26.1.025.

Suraci JP, Clinchy M, Zanette LY, Wilmers CC. 2019. Fear of humans as apex predators has landscape-scale impacts from mountain lions to mice. Ecol Lett 22 (10): 1578-1586. DOI: 10.1111/ele.13344.

Swan MP, Hickman DL. 2014. Evaluation of the neutrophil-lymphocyte ratio as a measure of distress in rats. Lab Anim 43 (8): 276-282. DOI: 10.1038/laban.529.

Szokalski MS, Litchfield CA, Foster WK. 2012. Enrichment for captive tigers (Panthera tigris): Current knowledge and future directions. Appl Anim Behav Sci 139 (1-2): 1-9. DOI: 10.1016/j.applanim.2012.02.021.

Tantius B, Wittschieber D, Schmidt S, Rothschild MA, Banaschak S. 2016. Two fatal tiger attacks in zoos. Int J Legal Med 130: 185-189. DOI: $10.1007 / \mathrm{s} 00414-015-1216-0$.

Theml H, Diem H, Haferlach T. 2004. Color Atlas of Hematology: Practical Microscopic and Clinical Diagnosis. Thieme New York, USA. DOI: 10.1055/b-005-148949.

Titisari N, Asri K, Fauzi A, Masnur I, Kurniawan I. 2019. Kadar hormon kortisol dan rasio neutrofil/limfosit (N/L) satwa lutung jawa pada saat di kandang perawatan dan kandang karantina di hutan Coban Talun, Batu. J Ternak Tropika 20 (1): 29-37. DOI: 10.21776/ub.jtapro.2019.020.01.4. [Indonesian]

Valenciano AC, Decker LS, Cowell RL. 2010. Interpretation of feline leucocyte response. In: Weis DJ, Wardrop KJ (eds). Schlam's Veterinary Hematology 6th Edition. Wiley-Blackwell Publishing, US. Vasconsellos AdS, Virányi Z, Range F, Ades C, Scheidegger JK, Möstl E, Kotrschal K. 2016. Training reduces stress in human-socialised wolves to the same degree as in dogs. PLoS One 11 (9): 1-19. DOI: 10.1371/journal.pone.0162389.

Vaz J, Narayan EJ, Kumar RD, Thenmozhi K, Thiyagesan K, Baskaran N. 2017. Prevalence and determinants of stereotypic behaviors and physiological stress among tigers and leopards in Indian zoos. PloS One 12 (4): 1-27. DOI: 10.1371/journal.pone.0174711.

Vidal LS, Guilherme FR, Silva VF, Faccio MCSR, Martins MM, Briani DC. 2016. The effect of visitor number and spice provisioning in pacing expression by jaguars evaluated through a case study. Braz $\mathbf{J}$ Biol 76 (2): 506-510. DOI: 10.1590/1519-6984.22814. 